九州大学学術情報リポジトリ

Kyushu University Institutional Repository

\title{
Succession and Sedimentary Features of the Lower Permian Sakamotozawa Formation
}

Kanmera, Kametoshi

Faculty of Science, Kyushu University

Mikami, Takahiko

Department of Earth Sciences, Yamaguchi University

https://doi.org/10.5109/1543634

出版情報：九州大學理學部紀要：Series D, Geology. 16 (3)，pp.265-274，1965-11-20. Faculty of Science, Kyushu University バージョン：

権利関係 : 
Mem. Fac. Sci., Kyushu Univ., Ser. D, Geol., Vol. XVI, No. 3,

pp. 265-274, 2 text-figs., November 20, 1965

\title{
Succession and Sedimentary Features of the Lower Permian Sakamotozawa Formation
}

By

\author{
Kametoshi Kanmera and Takahiko MIKami
}

\begin{abstract}
The stratigraphy and sedimentary features of the Sakamotozawa Formation, the type sequence for the Lower Permian Sakamotozawa Series of Japan, are described in this paper. The type Sakamotozawa Formation, about $270 \mathrm{~m}$ thick, is divided into two subformations separated by an unconformity. The Lower Subformation consists of a basal conglomerate and succeeding beds of sandstone and shale in the lower part and thin-bedded, mostly bioclastic limestone in the upper part. The Upper Subformation is made up of thin conglomerate at the base, thin- to thick-bedded bioclastic limestone in the lower part and sandstone and shale with some lenticules of limestone in the upper part. The limestone consists primarily of a number of small units, each of which is less than $25 \mathrm{~m}$ in thickness and characteristically represents a cyclic sedimentation. The litho- and bio-facies of the limestone as well as the stratigraphic sequence suggest an oscillating sedimentation under a gradual change of depositional conditions from a very shallow environment of a probably restricted water (possibly a lagoonal one), with an intermittent desication of water at times, to a slightly deepened somewhat off-shore environment of open neritic sea.
\end{abstract}

\section{Contents}

Introduction.............................................. Page

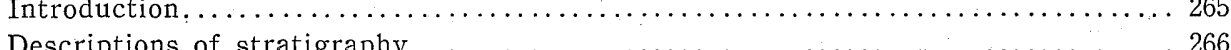

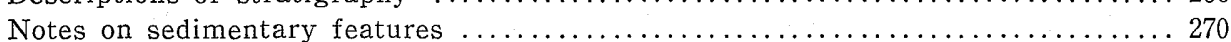

\section{Introduction}

The Sakamotozawa Formation in the Kitakami region, Northeast Japan, provides. the type sequence for the Sakamotozawa Series, a comprehensive biostratigraphic unit of the Lower Permian of Japan. While we are engaged in the biostratigraphic investigation of this type sequence, we have noticed some characteristic features in bio- and litho-facies of this formation. In this paper we describe the stratigraphic sequence and the sedimentary features of the Sakamotozawa Formation of the type area. Comments may be given to some extent from the standpoint of sedimentology.

A result of our biostratigraphic study is to be presented in a companion paper entitled "Fusuline Zonation of the Lower Permian Sakamotozawa Series".

Manuscript received July 10, 1965.

T. Mikami: Department of Earth Sciences, Yamaguchi University, Yamaguchi. 
Acknowledgements.-We wish to express our sincere gratitude to Prof. Tatsuro MATSUMoTo, who suggested and encouraged us to carry out this study and read the first draft of this paper with instructive advice on a number of important points. We gratefully acknowledge Dr. Koji FuJII and Mr. Kengo HyAKuTAKE of the Onoda Cement Company, Tokyo, and Mr. Masasuke KogA of the Ohfunado factory of the same company, who kindly offered every facility during our field work. Thanks are due to Miss Tomoko MryazAKI and Miss Misako KIDo for their assistance in typewriting and drafting. Financial aids were mainly granted by Ministry of Education.

\section{Descriptions of Stratigraphy}

The nomenclatorial derivation of the Sakamotozawa Formation is the Sakamotozawa Valley, Hikoroichi-machi, Ohfunado-city, Iwate Prefecture, on the northern and northwestern hillsides of which the formation is exposed here and there. Much better exposures are now afforded by quarries of the Nagaiwa mine in Nagaiwa, about $2 \mathrm{~km}$ north of Sakamotozawa. The stratigraphic sections were measured along several routes of these two areas and the fusulinaceans described in the companion paper were collected mainly from those sections (see Fig. 1).

The Sakamotozawa Formation of the areas, about $270 \mathrm{~m}$ thick, overlies the lower and middle Upper Carboniferous Nagaiwa Formation with a remarkable unconformity as clarified by MiNATO $(1941,1942)$, ONUKI (1956) and in particular precisely by YAMADA (1959). The lithology and succession of the formation have been set out by us as follows :

\section{A. Lower Subformation}

1. Basal part (Sa) $(30-55 \mathrm{~m})$.- - This begins with a basal conglomerate $(5-20 \mathrm{~m})$ and is succeeded by medium- to fine-grained, light greenish-grey, lithic to feldspathic, often calcareous sandstone and black shale in the middle and upper parts. In the middle part there are some calcareous silty sandstone beds with brachiopod shells. Another sandstone bed abundantly contains fusulinacean casts that are disposed mostly in the same direction. No specimens retaining their shells were obtained, but a majority of their moulds show a small subcylindrical species $(5-6 \mathrm{~mm}$ long, $1-1.5 \mathrm{~mm}$ wide) with a septal fluting similar to those of primitive species of Monodiexodina (Ferganites).

The shale of the uppermost part usually contains abundant, large crinoid columnals and plates and changes upwards into the limestone of the main part of the subformation. 2. Main part (Members $\mathbf{S b}_{1-3}$ ).-This occupies the lower half of the Sakamotozawa or the Shiratorizawa Limestone of authors. It shows cycles* of sedimentation which enable its subdivision into three members, $\mathrm{Sb}_{1}, \mathrm{Sb}_{2}$ and $\mathrm{Sb}_{3}$ in ascending order. a) Member $\mathbf{S} \mathbf{b}_{1}(30-35 \mathrm{~m})$ : i) Lower part.-Mostly 10 to $30 \mathrm{~cm}$, rarely up to $50 \mathrm{~cm}$ thick bedded, dark-grey algal biomicrudite dominated by an abundance of nodular $(2.5-5 \mathrm{~cm}$ long, $1.5-2 \mathrm{~cm}$ thick) to biscuit-shaped $(2.5-1.5 \mathrm{~cm}$ long, $1.0-0.5 \mathrm{~cm}$ thick) spongiostromid colonies (stromatolites), with a narrow matrix of fine lime mud. Fusulinaceans and brachiopods are also accompanied in some of these beds. Being intercalated in algal

\footnotetext{
* Progressive changes of the rhythmic sedimentation are summarized in page 270.
} 
beds there are occasional thin bands of crinoidal biomicrite and biosparite containing incomplete oöids in the lowest part. ii) Main part. $-50 \mathrm{~cm}$ to $1 \mathrm{~m}$ thick bedded, grey biomicrudite containing a large amount of fragmentary algal discs and/or biscuits $(0.5-1.5 \mathrm{~cm}$ long, $0.3-0.6 \mathrm{~cm}$ thick) of the same kind as the algal colonies in the lower and subordinate crinoid debris. Thin bands or partings of shale are occasionally intercalated.

Fusulinaceans occur commonly at several horizons of this member, and the shellshape of contained species and the mode of their occurrence correspond closely with the lithology of the beds.

b) Member $\mathbf{S b}_{2}(55-80 \mathrm{~m})$ : This member is best displayed in the Nishiyama quarries of the Nagaiwa mine, where it consists of four submembers, each of which is 15 to $25 \mathrm{~m}$ thick and shows a cyclic sedimentation. Each cycle begins with alternating beds of nodular to thin-bedded $(5-15 \mathrm{~cm})$ algal biomicrudite and reddish-purple limy clay (mostly less than $10 \mathrm{~cm}$ ), succeeded by 15 to $30 \mathrm{~cm}$ thick bedded, dark-grey biomicrite with some algal biomicrudite bands and ends with mostly thick-bedded $(50 \mathrm{~cm}-1 \mathrm{~m})$ to massive $(1-3 \mathrm{~m})$ biomicrite with occasional bands of biosparite. Thus in each cycle of this member sediments become gradually more thick-bedded, more light-coloured, finer in constituent-grains and less fossiliferous as the sequence goes upwards. It is also noteworthy that reddish-purple limy clay partings are accompanied in the lowest part of each cycle. At the base of this member there is a $50 \mathrm{~cm}$ thick, reddish-purple limy clay bed, and in the lowest cycle some thin bands of shale are intercalated in its lower part.

Fusulinaceans are found mostly in the brachiopod biomicrite beds just above the algal biomicrudite in the lower part of each cycle.

Member $\mathrm{Sb}_{2}$ in the Sakamotozawa area also shows cyclic sedimentation comparable to those of the Nagaiwa area.

c) Member $\mathbf{S b}_{3}(35-55 \mathrm{~m})$ : This member is mostly grey, thick-bedded crinoidal biomicrudite, but in the lowest part thin-bedded, dark-grey algal biomicrudite with some reddish clay partings is interbedded in some part, and in the middle part some thin beds of shale are intercalated. The biogenic constituents, except for the lowest part, are almost exclusively crinoid columnals and plates. In the type area they are rather well water-worn and seldom exceed $1 \mathrm{~cm}$ in size, but in the Nagaiwa area they are often as long as 3 to $5 \mathrm{~cm}$, not uncommonly $10 \mathrm{~cm}$, and are very poorly sorted. They are contained as much as $50 \%$, not uncommonly $80 \%$ of the total constituents of a given bed. The matrix is essentially a micritic fine lime mud, but in the Nagaiwa area it has been recrystallized to sparry mozaic calcite, retaining in part relicts of a fine lime mud.

In the lower and uppermost part of this member of the type area are intercalated a few beds of conglomeratic sandstone, feldspathic sandstone and shale.

Fusulinaceans were occasionally detected at a few horizons, but most of them are too much fragmentary to be determined.

\section{B. Upper Subformation}

This subformation rests unconformably on the Lower Subformation and is sub- 


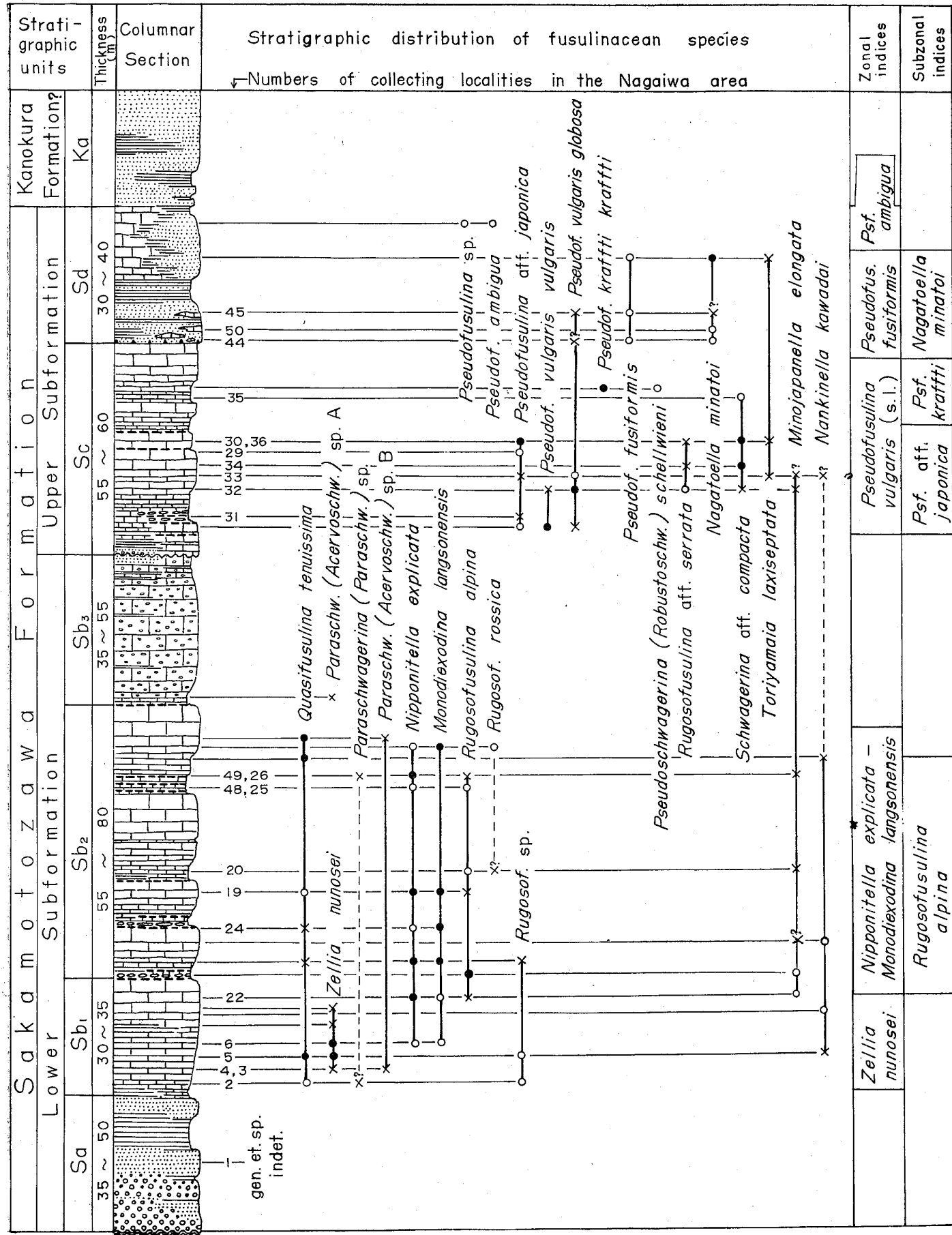

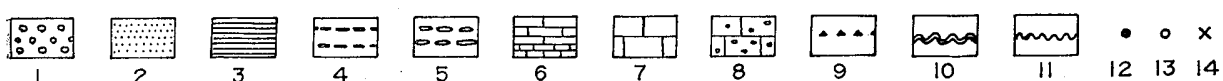

Fig. 1. Generalized stratigraphic section of the Sakamotozawa Formation of the SakamotozawaNagaiwa area, showing the distribution of the fusuline fossils.

1. conglomerate, 2. sandstone, 3. shale, 4. red limy clay, 5. nodular limestone, 6. thin-bedded limestone, 7. thick-bedded limestone, 8. richly crinoidal limestone, 9. iron bed, 10. unconformity, 11. disconformity, 12. abundant in occurrence, 13. common, 14. rare. 
divided into two members, the lower calcareous unit (Sc) and the upper less calcareous unit (Sd).

1. Main part (Member Sc) $(55-60 \mathrm{~m})$ : This member, which occupies the upper half of the Sakamotozawa or the Shiratorizawa Limestone of athors, is best displayed in the Higashiyama quarries of the Nagaiwa mine, where it shows cyclic or epicyclic sedimentation of three units. Its basal part, which consists of limestone-conglomerate, lies on Member $\mathrm{Sb}_{3}$ of the Lower Subformation with an irregular plane of unconformity showing a cross-cut relation of 20 to 30 degrees in strikes and about 10 to 15 degrees in dips*. In the Sakamotozawa area the base of this member is defined by a 1 to $4 \mathrm{~m}$ thick conglomerate bed which contains well rounded pebbles of chert and subrounded pebbles and granules of limestone and slate. This conglomerate unconformably overlies the sandstone in some parts and the limestone in other parts, both of Member $\mathrm{Sb}_{3}$, and is followed by a wedge-bed of sandstone (1-3 $\mathrm{m}$ ) and a sequence of thin-bedded biomicrudite and biomicrite $(50 \mathrm{~m})$.

In the Nagaiwa area the following succession is recognized:

a) Lower part $(10 \mathrm{~m})$.- The basal limestone-conglomerate $(10-30 \mathrm{~cm})$ contains limestone pebbles and granules and terrigenous sand. It grades upwards into grey massive well-sorted intrasparite $(7-9 \mathrm{~m})$. The succeeding bed is 20 to $50 \mathrm{~cm}$ thick bedded, gastropod and fusuline-gastropod biomicrudite $(2-2.5 \mathrm{~m})$. Each of the biomicrudite beds is accompanied with a reddish-purple limy clay bed $(10-20 \mathrm{~cm})$ at the top.

b) Middle part ( $\mathrm{ca} 20 \mathrm{~m}$ ).--This unit consists of nodular to 5 to $15 \mathrm{~cm}$ thick bedded, black biomicrudite in the lower $(2 \mathrm{~m}), 15$ to $25 \mathrm{~cm}$ thick bedded biomicrudite and biomicrite in the middle $(14 \mathrm{~m})$, and three beds of 1 to $1.5 \mathrm{~m}$ thick bedded, dark-grey biomicrudite containing pisolitic or biscuit-shaped algal growths in the upper part (4$4.5 \mathrm{~m}$ ). At the top of each bed of the lower and middle parts occur partings of reddish-purple limy clay.

The middle unit is highly fossiliferous at many levels. Especially thin-bedded biomicrudite in its lower part is teemed with well-preserved dasycladacean algae (mainly Mizzia) which are accompanied with remains of simple corals, tabulate corals (mainly Michelinia), gastropods, pelecypods and foraminifers including fusulinaceans.

The calcareous sediments of this unit, alike those of Member $\mathrm{Sb}_{2}$, become more thick-bedded, more light-coloured, finer in constituent-grains and less fossiliferous as we ascend the sequence, but the uppermost part again assumes dark-coloured and is highly fossiliferous in part.

Fusulinaceans, which occur abundantly at many horizons, are mostly of thick fusiform shape such as Pseudofusulina vulgaris (ScHELlwiEN) (s.l.) and P. ambigua (DEPRAT). In the lower part they are scattered at haphazard, but in the uppermost part they are often concentrated in laminae keeping a constant direction of shells. c) Upper part ( ca $25 \mathrm{~m}$ ).-This unit is composed of 10 to $20 \mathrm{~cm}$ thick bedded, dark-grey algal biomicrudite with some reddish-purple limy clay partings in the lower $(2 \mathrm{~m})$, 20 to $40 \mathrm{~cm}$ thick bedded, dark-grey biomicrite in the middle $(12 \mathrm{~m})$, and 1 to $1.5 \mathrm{~m}$ thick

* Member $\mathrm{Sb}_{3}$ of the Lower Subformation and the Upper Subformation show clear differences from each other in cleavage and minor folding. These and other details of the unconformity are explained in another paper written in Japanese (MIKAMI, 1965). 
bedded, grey biomicrite with thin-bedded biomicrite in the upper $(10 \mathrm{~m})$. The calcareous sediments of this unit are less fossiliferous and better-sorted than those of the lower and middle units.

2. Uppermost part (Member Sd) (30-40 m) : As this member is poorly exposed in the surveyed area, its succession cannot be known so precisely as in the underlying beds. It is, however, composed mainly of alternating shale and sandstone of various thickness usually $1 \mathrm{~m}$ or so, with some limestone. In general shale is predominant in the lower part, while sandstone becomes thicker in the upper part. Limestone of the lower part is lenticular, less than $2 \mathrm{~m}$ in thickness. That of the upper part is often thinly alternating with sandstone and shale in the Nagaiwa area and is more or less argillaceous and becomes thick-bedded in the Sakamotozawa area. Fusulinaceans such as Pseudofusulina fusiformis (SCHELLWIEN) and Nagatoella sp. nov. are abundant in many of the limestone lenses of the lower part, but they are poor in preservation, sometimes replaced with silica by secondary mineralization.

The Upper Subformation is conformably overlain by a sequence of strata $(30-50 \mathrm{~m})$ consisting mainly of coarse-grained sandstone with intercalation of a few thin beds of pebble-conglomerate and some layers of shale. The shale layers are less than $5 \mathrm{~m}$ in thickness. No fossils have been found from them. We provisionally refer them to the lower part of the Kanokura Formation which is typically exposed in the Kanokura Valley, about $15 \mathrm{~km}$ west of this area. It should be noted here, however, that Minato et al. (1965) infer the existence of an unconformity between the Sakamotozawa and the overlying Kanokura Formation from the results of their detailed mapping. To draw our conclusion about this problem further study of much wider areas including the type-section of the Kanokura Formation is needed.

\section{Notes on Sedimentary Features}

In the preceding chapter of stratigraphy the litho- and bio-facies are described to some extent for each member of the Sakamotozawa Formation. In this chapter remarks are given from the standpoint of sedimentology.

The main part of the Sakamotozawa Formation from Member $\mathrm{Sb}_{1}$ to Member $\mathrm{Sc}$ consists primarily of limestone. This part is conventionally called the Sakamotozawa Limestone. On the basis of the described facts the remarkable features in the sedimentary facies of the Sakamotozawa Limestone may be summarized and commented as follows:

a) The Sakamotozawa Limestone consists of nine units, each of which shows a cyclic sedimentation. As is well exemplified in Member $\mathrm{Sb}_{2}$ and many other members, each of these units begins with, or contains dominantly in the lower part, dark-grey to black, slightly arenaceous or argillaceous, thin-bedded, mainly algal biomicrudite, often with thin shale bands and reddish-brown limy clay partings. As the sequence is followed upwards the limestone becomes gradually thick-bedded, lighter-coloured, better-sorted and finer-grained, and consists of water-worn, mixed bioclastic debris of variety of organisms. Especially richly crinoidal limestone is predominant in the 
middle part of each member.

b) The biomicrudites of the lower part of each cycle are richly algal, teeming with nodular to biscuit-shaped spongiostromid colonies and subordinately accompanied with. some other kinds of algae, gastropods, brachiopods and fusulinaceans. The algal nodule ranges mostly from 1 to $4 \mathrm{~cm}$ in diameter and from 0.5 to $1 \mathrm{~cm}$ in thickness. It has a shelly or other biogenic detrital core and a rather smooth outer surface. The nodules are regularly arranged with a longer axis parallel to the bedding plane. They never coalesce with one another into large masses or sheets, as often seen in reefbuilding stromatolites which are, as drawn by ANDERSON (1950), commonly humped up into more or less irregular domes or digitate or turbinate columns from a common base. They are so abundant in many layers as to occupy more than $70 \%$ of the whole rock of a given bed. Much of the matrix in which the nodules rest is a poorly sorted. micritic lime mud or calcite mudstone, and the contained shells are often almost: complete. These algal beds show no signs of significant winnowing of the sediments.

Nodular algal structures developed in connection with the growths of living bluegreen algae have been recorded from many places. The environmental condition common to these places is swampy or lagoonal in a general sense or of coastal flats of a saline lake, in which the water is very shallow and heavily charged with calcium carbonate ions. A well described example of algal nodules or biscuit-shaped algal growths in process of formation is that in the swamps of the mouth of the River Murray in Victorian border, South Australia (MAWSON, 1929), to which the Sakamotozawan algal growths display a close resemblance. The algal limestone precisely described by GEORGE (1960) from the Lower Carboniferous of County Wexford, Ireland,* is a good example of nodular algal structures in geologic times. Although they are dominantly of codiaceans and subordinately of several kinds of spongiostromids, the general features of the algal growths and the broad aspects of the limestone are closely similar to those of the Sakamotozawa Limestone. GEORGE considers that the facies. of the algal limestone and the overlying calcite-mudstone of Wexford is lagoonal in a general sense and that the deposition is on flats and in shallows with some intertidal. conditions.

c) Deposition in very shallow and quiet water condition is also suggested by the facies of the middle submember of Member Sc. Its lower part contains abundant dasycladacean algae made up mainly of Mizzia. They are so well preserved that. their moniliform thalli are almost complete. The associated gastropods, pelecypods, simple corals and fusulinaceans are also well preserved. These algal beds are thinbedded $(5-15 \mathrm{~cm})$ and show no or little signs of significant winnowing of the sediments. by currents and agitation of water.

d) In most members, the algal limestone also occurs fairly commonly in the middle part and occasionally in the upper part. The algae are accompanied not uncommonly with fusulinaceans and rich crinoid debris. The contained spongiostromids are, however, much smaller than those in the limestone of the lower part and not uncommonly

* One of us (K.K.) fortunately had an opportunity of examining and collecting the algal limestone in Wexford under the guidance of Prof. T. N. GEORGE of the University of Glasgow, to whom he is deeply indebted. 
fragmentary. They comprise small, platy or disc-shaped colonies less than $0.5 \mathrm{~mm}$ in thickness. There are also many encrusting forms, which constitute thin films or 0.5 to $1.5 \mathrm{~mm}$ thick laminated layers. They enclose organic debris of various sizes. Dasycladacean algae are also fairly common, but they are almost fragmentary and occupy the cores of encrusting algal growths.

e) The layers of limestone of the middle and upper parts in each cycle are generally thick-bedded (30-50 cm, rarely up to $1 \mathrm{~m}$ ) and clearly show evidence of winnowing. The contained fossils are therefore mostly fragmentary and water-worn. Fusulinaceans of elongate subcylindrical shape and platy or disc-shaped spongiostromid colonies are often concentrated in bands or laminae showing a parallel alignment.

The matrix of the limestone is made up of mixed organic debris of medium- to fine-grained sand-size, with a very narrow interstices usually filled with sparry calcite cement. The disposition of the constituents and the nature of the matrix suggest the deposition in a normal neritic environment affected by some agitating water or currents of moderate velocity. The disc-shaped small algal colonies are considered to have been transported from nearby shallower living sites.

f) In the lower part of several members the limestone of many of the algal beds, regardless of the composing nodular spongiostromids or dasycladaceans, is followed by a thin layer (commonly $10-3 \mathrm{~cm}$, rarely up to $20 \mathrm{~cm}$, in thickness) of reddish-brown ferrugenous limy clay with a gradual change from the lower dark-coloured fossiliferous limestone. There are not a few beds of limestone, in which the uppermost part has been more or less stained into reddish-brown colour. These limy clay layers and stained parts of limestone are considered to have been produced from originally darkcoloured marine limestone by oxidation and precipitation of contained ferrous contents with more or less leaching of calcium carbonate. This interpretation may be supported by the fact that these parts often contain remains of algae, fusulinaceans, gastropods, pelecypods etc., which have also been completely decalcified to casts or markedly stained. It is assumed that this weathering was taken place penecontemporaneously with or immediately after the deposition of a given bed in a very shallow-water condition and before the accumulation of a succeeding bed.

Examples of the reddish-brown clay layers are most typically developed in the lower part of Member $\mathrm{Sb}_{1}, \mathrm{Sb}_{2}, \mathrm{Sb}_{3}$ and $\mathrm{Sc}$ and less so or lacking in the middle and upper parts of these members. Repeated occurrence of these kinds of layers at many horizons in the Sakamotozawa Limestone reveals the episodic desication of the shallow flats and penecontemporaneous weathering without significant erosion and inflow of terrestrial material from the land areas which must have been topographically very low.

Summarizing the above described analysis of litho- and bio-facies as well as the stratigraphic sequence, the following conclusion may be led. The Sakamotozawa Limestone consists of a number of units, each of which represents a minor cycle of sedimentation. Each unit was formed under a gradual change of depositional conditions from a very shallow environment of a probably restricted water (possibly a lagoon), with an intermittent desication of water at times, to a slightly deepened near-shore 
to somewhat offshore environment of open neritic sea where winnowing of sediments was taken place by agitating water or currents of moderate intensity.

The basal part (Member Sa) of the Sakamotozawa Formation, which consists of the basal conglomerate, fossiliferous sandstone, and shale, represents the beginning of a major marine transgression onto the land of moderate relief. The topographic relief, however, must have been very low during the main period of the formation, i. e. the Sakamotozawa Limestone. In addition to the oscillation of the shallow depositional basin as shown by the above mentioned cyclic, calcareous sedimentation, an episodic but unnegligible upheaval of the area of sedimentation is recorded by an unconformity between Members $\mathrm{Sb}_{3}$ and Sc. The uppermost part of the Sakamotozawa Formation, i.e. Member Sd, has predominant shale and sandstone with some limestone. This may represent the last phase of the major sedimentary cycle, but some problems remain unsettled as regards its depositional condition and its relation with the Kanokura Formation. 


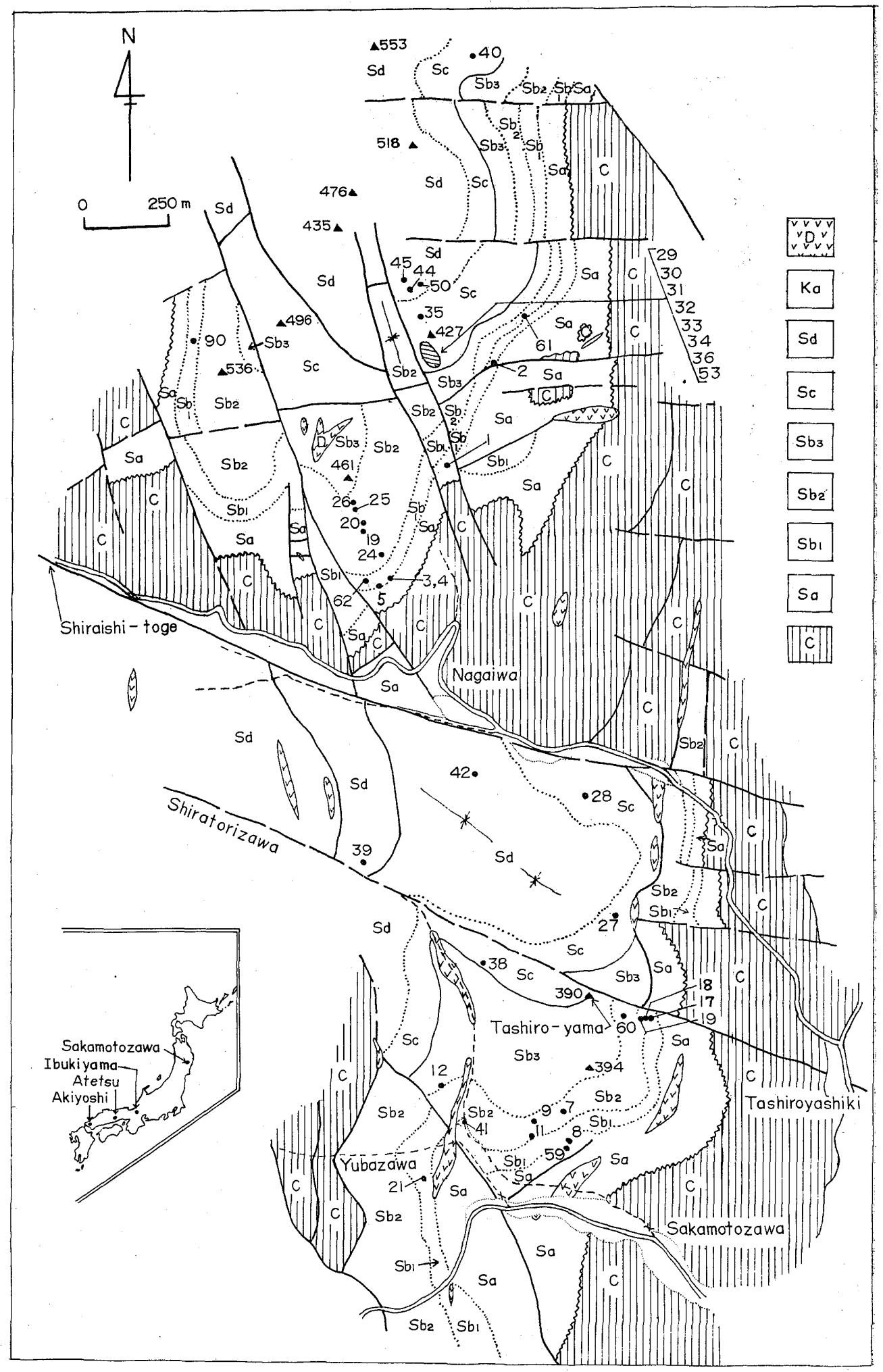

Fig. 2. Simplified geological sketch-map of the Sakamotozawa-Nagaiwa area, showing important collecting localities of fusuline fossils.

C. Pre-Permian formations, Sa-Sd. Sakamotozawa Formation, Ka. Kanokura Formation, D. Dyke rocks. Prefix Ks should be put for every collecting locality. 